\title{
USE OF RESIDUES FROM THE SUGAR AND ALCOHOL INDUSTRY IN THE DEVELOPMENT OF SUGARCANE SEEDLINGS
}

\author{
Rodrigo Garcia Brunini ${ }^{1}$, Fábio Luiz Costa ${ }^{2}$ \\ ${ }^{1}$ Universidade Estadual Júlio de Mesquita Filho. E-mail: rgbrunini@gmail.com \\ ${ }^{2}$ Instituto Taquaritinguense de Ensino Superior. E-mail: fabiocosta3237@ gmail.com
}

\section{ABSTRACT}

The sugar and alcohol industry generates direct consumption products such as sugar and ethanol and organic residues. The use of new techniques in management of sugarcane seedlings taking advantage of the by-products generated by the industry is a profitable alternative to contribute in the productive potential, economy in the use of fertilizers, and reduction of the impacts these residues have in the environment. The objective of this study was to analyse the rate of sprouting and tillering of sugarcane cultivated under different types of residues. The research was developed in an experimental area in the municipality of Guariba, in the state of São Paulo, Brazil. The sugarcane was cultivated under soot and filter cake: in natura, tanned and enriched. The development was influenced by the different residues, and the treatment under enriched filter cake presented a higher sprouting rate and dry shoot mass, while $100 \%$ of the seedlings died in the treatment with filter cake in natura.

Keywords: Buds, filter cake, sprouting, Saccharum officinarum, tillering

\section{USO DE RESÍDUOS DA INDÚSTRIA SUCROALCOOLEIRA NO DESENVOLVIMENTO DE MUDAS PRÉ-BROTADAS DE CANA-DE-AÇÚCAR}

\section{RESUMO}

A indústria sucroalcooleira gera produtos de consumo direto como o açúcar e etanol e subprodutos (resíduos orgânicos). Utilizar novas técnicas no manejo de mudas pré brotadas aproveitando os subprodutos da cana-de-açúcar é uma alternativa para contribuir com o potencial produtivo, economia no uso de adubos e fertilizantes e diminuição dos impactos destes resíduos ao meio ambiente. Objetivouse com este trabalho analisar a taxa de brotação e perfilhamento da cana-de-açúcar cultivada sob diferentes tipos de resíduos oriundos da indústria sucroalcooleira. A pesquisa foi desenvolvida em uma área experimental no município de Guariba, estado de São Paulo, Brasil. A cana-de-açúcar foi cultivada sob fuligem e torta de filtro: in natura, curtida e enriquecida. O desenvolvimento da cana-de-açúcar, 
sofreu influência dos diferentes resíduos, sendo que o tratamento sob torta de filtro enriquecida apresentou maior taxa de brotação e massa seca da parte aérea, enquanto que $100 \%$ das mudas morreram no tratamento com torta de filtro in natura.

Palavras-chave: Brotação, gemas, perfilhamento, Saccharum officinarum, torta de filtro

\section{INTRODUCTION}

Brazil is the largest producer of sugarcane in the world, followed by India, China and Thailand. The sugar and alcohol sector is essential for the national economy, it is known that sugarcane raw materials can produce: sugar, anhydrous ethanol (gasoline additive) and hydrated ethanol, for the domestic and foreign markets, including the use of biofuel as an alternative energy. The State of São Paulo is considered the main producer of sugarcane, with the regions of Barretos, Ribeirão Preto, Franca, and Piracicaba being the most productive ones (CTC, 2015).

About 400 sugar and alcohol factories are responsible for the production of 28.6 billion liters of ethanol and 35 million tons of sugar, from 634.9 million tons of sugarcane processed in 2014/2015. The industrial efficiency is $91 \%$, generating residues such as vinasse, filter cake, ash, and lubricating oils which comprise $9 \%$ remaining. In 2009, agro-industries associated with agriculture produced 290.8 tons of organic residues, with $69 \%$ of sugarcane bagasse and filter cake in the Southeast region (CONAB, 2016).

Several residues of sugar and alcohol production can be used as fertilizers in the cultivations, with the objective of minimizing impacts to the environment, adequate destination of slags in crops and increased economic viability in the use for organic fertilization. The most used wastes at sugarcane cultivation areas are the vinasse and filter cake, due to the large amount of these by-products that are available betweenthe harvests.

The filter cake is rich in nutrients such as phosphorus and calcium, presents about $70 \%$ moisture in its mass, a factor of great importance to ensure the sprouting and the tillering of the crop between cultivations, mainly in the winter. Soon after the removal of the cake in the rotary filter, a composting process is carried out in order to adjust the organic matter concentration and the amount of microorganisms present in the residue, obtaining the tanned filter cake (VITTI et al., 2006).

It is common for producers to add mineral fertilizers such as phosphorus, nitrogen and potassium in the tanned filter cake, since it does not contain all the nutrients needed to meet the needs of the crop, getting the enriched filter cake like final raw material (ALMEIDA JÚNIOR et al., 2011). 
Another important residue from sugarcane is the soot (ash), obtained from the burning of bagasse, due to its high calorific value in the generation of steam and electricity in the sugar and alcohol industry. The bagasse used in this process has an ash yield of $10 \%$ by mass, being collected at the base of the gas scrubber of the boiler. The soot is composed mainly of carbon (5\%), silicon dioxide - $\mathrm{SiO}_{2}$ (above $60 \%$ by mass), iron, aluminium, and other molecules (PAULA et al., 2009). The higher the amount of $\mathrm{SiO}_{2}$, the more toxic the ash is, being one highly harmful residue to the environment and requires proper disposal.

The sugar cane is commercially grown through sprouts, which is the part of the plant responsible for storing water, mineral reserves and important hormones in the development of shoots and tillers. This management practice is considered costly and requires more than $20 \%$ of the total cost of production and renewal of sugarcane cultivation.

According to Landell et al. (2012), in the pre-sprouted seedlings system, there is a greater productive potential in the cultivated areas and economy in the sector, due to the decrease of the number of buds used per area, the high capacity of response in the field and the positive influence in use of water and soil.

Due to the sugar and alcohol sector being in constant technological development, it is necessary to carry out studies on the rational use of residues and organic compounds, arising from this activity in the development of sugarcane seedlings, which is the essential raw material to increase the quality of the technological management and the disposal of by-products generated by the sector.

For Schneider et al. (2013), the use of waste from the sugar and alcohol sector is an economically viable option for organic fertilization in sugarcane cultivation, in addition not being misused and causing potential impacts to the environment in the future.

The objective of this work was to analyse the rate of sprouting and tillering of sugarcane cultivated under different types of residues and organic compounds from the sugar and alcohol industry.

\section{MATERIAL AND METHODS}

The research was carried out in an experimental area located in the municipality of Guariba, state of São Paulo, Brazil, 21 21'34.03" of South Latitude and 48¹3'22.14" of Longitude West. The climatic classification for the region, according to Köppen, is of type Cwa: mesothermic climate of dry winter, in which the average temperature of the warmer month is superior to $22^{\circ} \mathrm{C}$ and the one of the coldest month 
inferior to $18^{\circ} \mathrm{C}$ (PEEL et al., 2007). The average annual precipitation varies from $1.100 \mathrm{~mm}$ to 1.700 mm (DONADIO et al., 2005).

In this area, trays with $0.45 \mathrm{~m}^{2}$ of area $(0.70 \mathrm{~m} \times 0.65 \mathrm{~m} \times 0.10 \mathrm{~m})$ were planted, where the sugarcane variety RB975952 was cultivated, having excellent sprouting, high yield and high content of sucrose (RIDESA, 2015), through cultivation the individualized buds, removed from the middle third of the primary plants, with a better phytosanitary aspect, absent from pests and mechanical damages, 20 per tray according to the method proposed by Landell et al. (2012), directly under different by-products (residues and compounds) of sugarcane, totalling four treatments (T1, T2, T3, and T4), being these:

- T1 (sugarcane grown under soot);

- T2 (sugarcane grown under tanned filter cake);

- T3 (sugarcane grown under filter cake in natura); and

- T4 (sugarcane grown under enriched filter cake with phosphorus in the form of natural phosphate of Araxá $\left(4 \% \mathrm{P}_{2} \mathrm{O}_{5}\right)$, nitrogen in the form of urea $(45 \% \mathrm{~N})$, and potassium in the form of potassium chloride $\left(60 \% \mathrm{~K}_{2} \mathrm{O}\right)$, according to the method used by González et al. (2014).

All the residues used in this work came from a sugarcane industry that carries out activities in the region of the experiment.

For each treatment, five replications were performed at random in the experimental area, totalling twenty trays with a total area of $2.25 \mathrm{~m}^{2}$ per mean of treatments.

The experiment was conducted in the period from April 3 to May 22, 2016 (sprouting and tillering phases of the sugarcane). In this period, the sprouting rate and tillering rate of sugarcane were evaluated every seven days after emergence (d.a.e.) according to the methodology proposed by Marafon (2012).

On May 22 (49 d.a.e.) the sugarcane was harvested, the roots and the tillers for each treatment were properly separated, stored in paper bags and placed for drying for 72 hours. After drying the aerial part and roots were weighed on a digital scale (in milligrams) and the dry mass of the aerial part and roots was calculated for each treatment.

The meteorological data regarding the period of implantation and conduction of the experiment were provided by the Automated Meteorological (Davis Instruments) Station of the University of Agricultural and Veterinary Sciences (UNESP), Jaboticabal, state of São Paulo, Brazil.

The method proposed by Casaroli \& Quirijin (2008) was adapted, keeping all the treatments in vase capacity, just during the germination phase and to favor the water conditions necessary for the 
beginning of the development of the sugarcane (LANDELL et al., 2012). Irrigation was performed late in the afternoon using a bottle of known volume $(300 \mathrm{~mL})$.

The obtained data were submitted to analysis of variance by the Tukey test at $5 \%$ probability in the Assistat ${ }^{\circledR}$ software (The Assistat Software Version 7.7).

\section{RESULTS AND DISCUSSION}

Figure 1 presents the variation of precipitation and temperature in the data collection period (April and May 2016), totalling 49 days after emergence. Between 42 and 49 d.a.e (May), the largest accumulate precipitation occurred (about $32 \mathrm{~mm}$ ). While in April (0 to 28 d.a.e), the precipitation occurred only in the last week $(9 \mathrm{~mm})$.

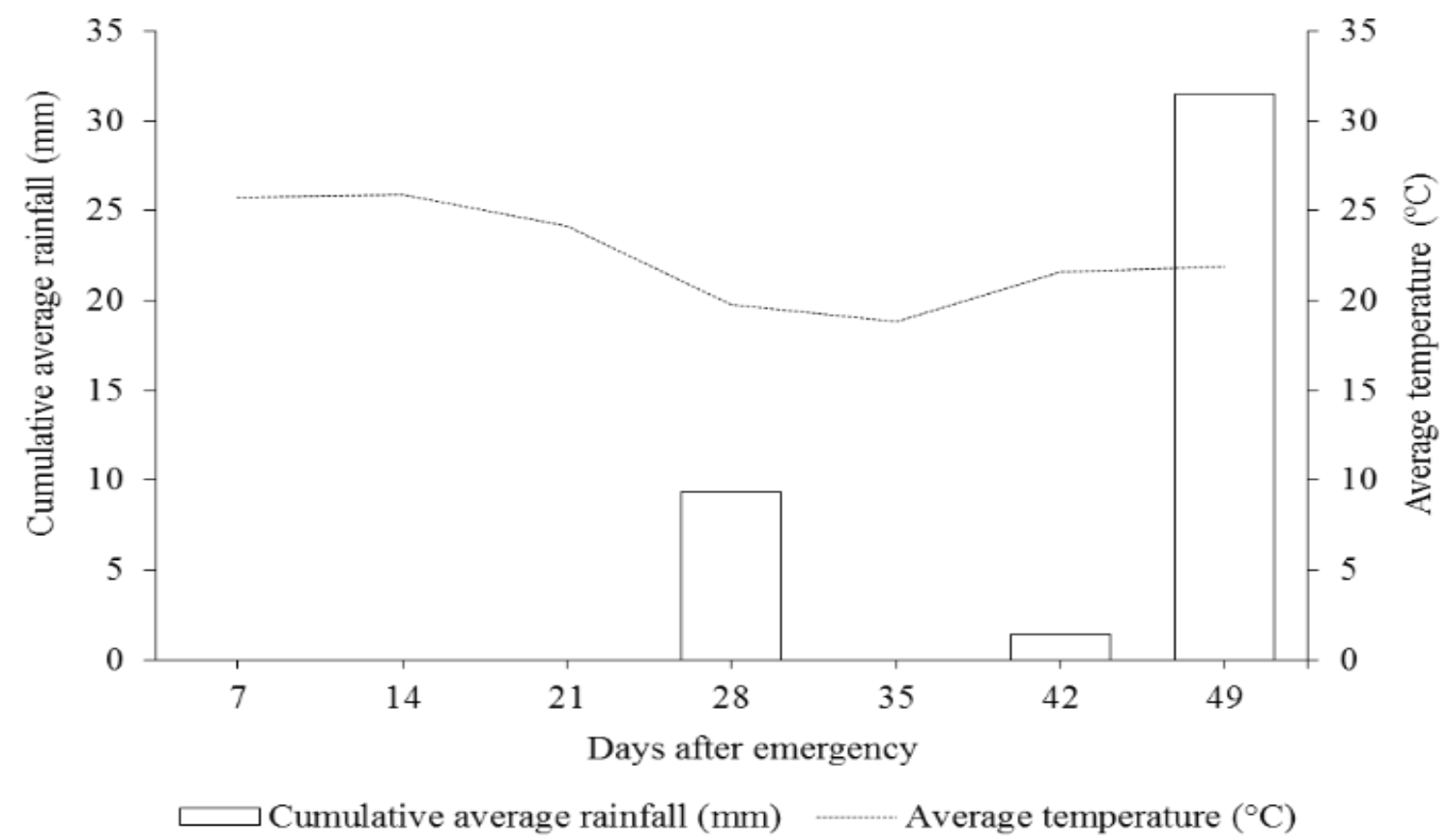

Figure 1. Temperature in ${ }^{\circ} \mathrm{C}$ and precipitation in $\mathrm{mm}$, occurred during the conduction of the experiment.

For the authors Vasconcelos \& Garcia (2005) and Landell et al. (2012), the water availability is the main factor responsible for the beginning of the sprouting process of the sugarcane buds and is reduced gradually according to the development of roots and tillers, which contributed in the experiment to guarantee the ideal conditions of roots growth in the buds for the different evaluated treatments.

Regarding the average temperature for the period, it is observed that the highest temperature occurred between 7 a.m. and 14 d.a.e. $\left(25.9^{\circ} \mathrm{C}\right.$.) and the lowest temperature recorded at the 35 d.a.e (18.9 ${ }^{\circ} \mathrm{C}$.). According to Serafim et al. (2013), several environmental factors influence the sprouting rate of the 
crop during the initial development phase, having a great influence on the physiological processes that occur in the buds.

For Jadoski et al. (2010), the sprouting and tillering of sugarcane are directly affected by soil moisture, luminosity and temperature, increasing up to a maximum of $30.0^{\circ} \mathrm{C}$ and above this value the sugarcane can suffer losses in the number of buds and tillers. In this way it is possible to verify that for all the treatments climatic conditions of temperature and humidity were favorable the phases of sprouting and tillering, not suffering water stress and or thermal stress during the period of study.

The sprouting rate is observed in Figure 2, up to 28 d.a.e, for the different treatments.

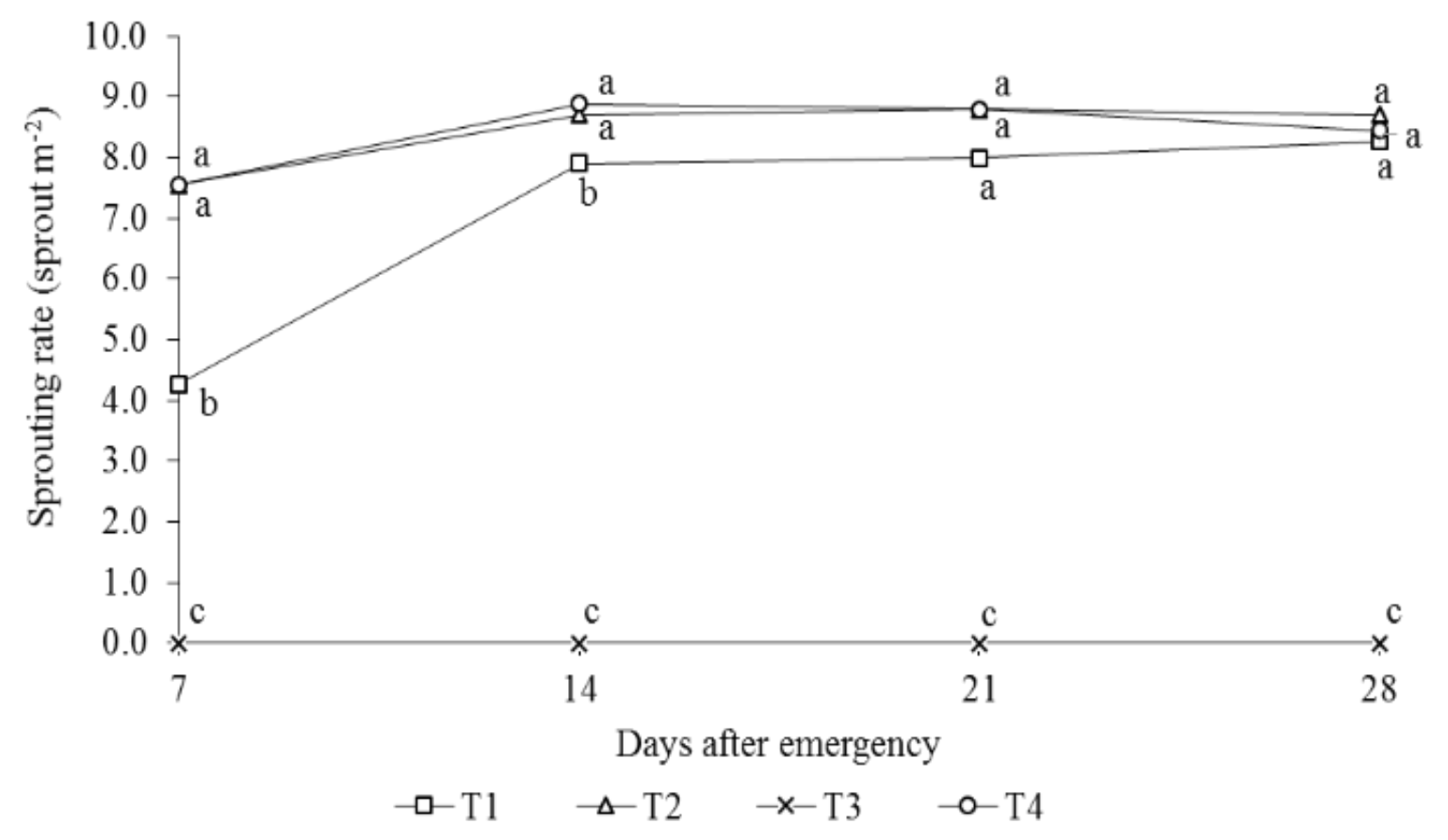

Figure 2. Sprouting rate of sugarcane, sprout per $\mathrm{m}^{2}$, for the treatments. Symbols with equal letters for the same date do not differ from each other by the Tukey test, at $5 \%$ probability. CV $=12.44 \%$.

Observing the treatments T2 (sugarcane cultivated under tanned filter cake) and T4 (sugarcane cultivated under enriched filter cake), it was verified that there was no statistical difference between 7 and 28 d.a.e for the averages found in the number of sprouts reaching a maximum of 8.7 sprouts $\mathrm{m}^{-2}$, respectively and followed by treatment T1 (sugarcane cultivated under soot), which presented lower average values were between 7 d.a.e $\left(4.3\right.$ sprouts $\mathrm{m}^{-2}$ ) and at 14 d.a.e (with about 7.9 sprouts $\mathrm{m}^{-2}$ ) respectively and not differing from T2 and T4 treatments after 21 d.a.e. 
The three treatments (soot, tanned filter cake and enriched filter cake) were able to maintain the development conditions of the sprouts favorable to the sugarcane cultivation and retain the available water and the temperature in a range suitable for the sprouts and roots of plants.

Liu et al. (1998) cite the importance of carefully observing all aspects of management related to the sprouting phase of the sugarcane crop, because at this stage of the cycle the plant is mainly dependent on the humidity conditions of the production environment and of the temperature.

For the treatment T3 (sugarcane cultivated under filter cake in natura), it is verified that the residue composed of filter cake in natura did not allow the development of the sprouts $\left(0.0\right.$ sprouts $\left.\mathrm{m}^{-2}\right)$ (Figure 2), and consequently of the tillers $\left(0.0\right.$ tiller $\left.\mathrm{m}^{-2}\right)$ (Figure 3$)$. This fact can be explained due to fermentation of the organic residue, which occurred in all five replications, a process that led to the "total baking" of the buds, due to the high temperatures generated during the fermentation and that made the environment unfeasible for the adequate development of the plants.

According to Cortez et al. (1992), in the filter cake in natura the anaerobic fermentation process releases large amount of energy in the form of heat (temperatures above $70{ }^{\circ} \mathrm{C}$ ) and evaporates part of the water contained in it, reducing its humidity for under values to $20 \%$.

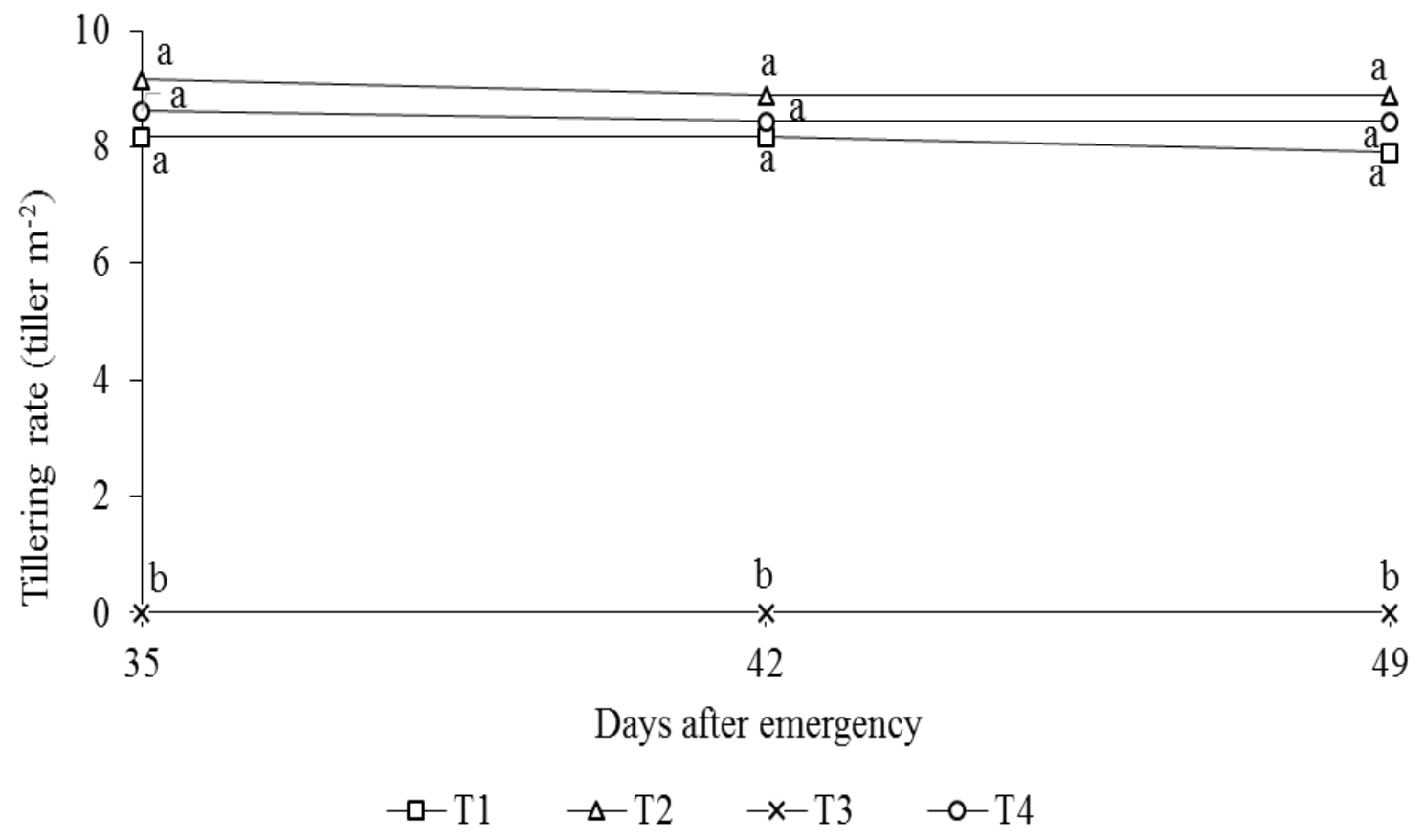

Figure 3. Tillering rate of sugarcane, tillers per $\mathrm{m}^{2}$, for the treatments. Symbols with equal letters on the same date, do not differ from each other by the Tukey test, at $5 \%$ probability. $\mathrm{CV}=10.82 \%$. 
For the tillering rate of sugarcane (Figure 3) there was no significant difference from 35 to 49 days after emergence for treatments T2, T4 and T1, of which presented a mean value of 9.0, 8.4 and 7.9 tillers $\mathrm{m}^{-2}$ respectively at 49 d.a.e. It is known that with the development of the root system (end of the sprouting phase) and the expansion of the leaves (beginning of tillering), the plant then begins to withdraw water and nutrients from the soil more sharply, initiating the dependent metabolic processes of photosynthesis (MARAFON, 2012).

In this sense, T2 and T4 treatments stand out, as both have nutrients in the residue that favored the formation and generation of new tillers more homogeneously.

According to studies accomplished by De Almeida et al. (2008) and Tavares et al. (2010), evaluating the tillering rate for sugarcane cultivated under Latosol and Argisol without the use of residues or mineral fertilizers, the average values found were 10.5 sprouts $\mathrm{m}^{-2}$ and 14.6 tillers $\mathrm{m}^{-2}$, respectively. Indicating that the use of organic residues such as soot, tanned filter cake and enriched filter cake in different types of soils may contribute positively to the tillering rate, increasing the quality of the environment and the development potential The technology of sugarcane seedlings.

Table 1 shows the mortality rate in percentage (\%) of sprouts and tillers for each of the treatments.

Table 1. Mortality rate, sprouts and tillers in $\%$, for the treatments during of development stages of the sugarcane cultivation.

\begin{tabular}{ccccc}
\hline Mortality & \multicolumn{5}{c}{ Treatments* } \\
\cline { 2 - 5 }$(\%)$ & $\mathrm{T} 1$ & $\mathrm{~T} 2$ & $\mathrm{~T} 3$ & $\mathrm{~T} 4$ \\
\hline Sprouts & 0.0 & 1.0 & 100.0 & 5.0 \\
Tillers & 3.3 & 2.9 & 100.0 & 2.0 \\
\hline
\end{tabular}

*T1 = sugarcane grown under soot; $\mathrm{T} 2$ = sugarcane grown under tanned filter cake; $\mathrm{T} 3$ = sugarcane grown under filter cake in natura; $\mathrm{T} 4=$ sugarcane grown under enriched filter cake.

It is observed that, in the T3 treatment, there was a mortality rate in $100 \%$ of the sprouts, avoiding the formation and tillers, due to the fermentation process of the filter cake residue in natura and the accentuated decrease of the humidity in the environment of cultivation for sugarcane seedlings. Data that corroborate with Jadoski et al. (2012) and Alves et al. (2015), the authors carrying out studies with the conventional planting system and sugarcane seedlings indicate that the higher mortality of seedlings is directly related to the water availability of the productive environment.

During the sprout phase of the culture, the treatment with enriched filter cake (T4) presented 5\% mortality, followed by $\mathrm{T} 2$, with $1 \%$, suggesting that the use of the tanned or enriched filter cake could 188 
interfere in the development of the sprouts according to the amounts applied in the cultivation of sugarcane seedlings, as well as by enrichment by other nutrients. In the treatment with soot (T1), it was verified that this by-product of sugar and alcohol industry did not interfere in the development of the sprouts ( $0 \%$ of mortality), showing be an interesting residue for the use in the initial phase of the production in sugarcane seedlings.

In the tillering phase of the culture, the treatment with enriched filter cake (T4) had the lowest mortality value about $2 \%$, followed by treatments T2 and T1, with 2.9 and $3.3 \%$ respectively. During the tillering phase, the sugarcane cultivation demands a greater amount of nutrients for the tillers, in this sense the T4 with the enriched filter cake stands out.

For Oliveira et al. (2014), environmental factors such as variations in temperature, nutrients, water availability, and luminous intensity (solar radiation) are the main factors responsible for affecting the metabolic and energetic processes of sugarcane. This fact may explain the higher occurrence of mortality for treatments $\mathrm{T} 1$ and $\mathrm{T} 2$, because the nutritional composition present in these residues is lower than the enriched filter cake.

There is little scientific literature on the subject regarding the possible causes of mortality in sprouts and tillers in the system of production of sugarcane seedlings.

According to Figure 4, dry mass of roots in grams per $\mathrm{m}^{2}$ was higher in treatments $\mathrm{T} 2$ and $\mathrm{T} 4$, with 14.2 and $16.8 \mathrm{~g} \mathrm{~m}^{-2}$, respectively, and did not differ statistically each other (Table 2). For the treatment $\mathrm{T} 1$, it can be observed that the sugarcane seedlings cultivated under soot presented a lower result, $5.8 \mathrm{~g} \mathrm{~m}^{-2}$, for dry mass of roots. 


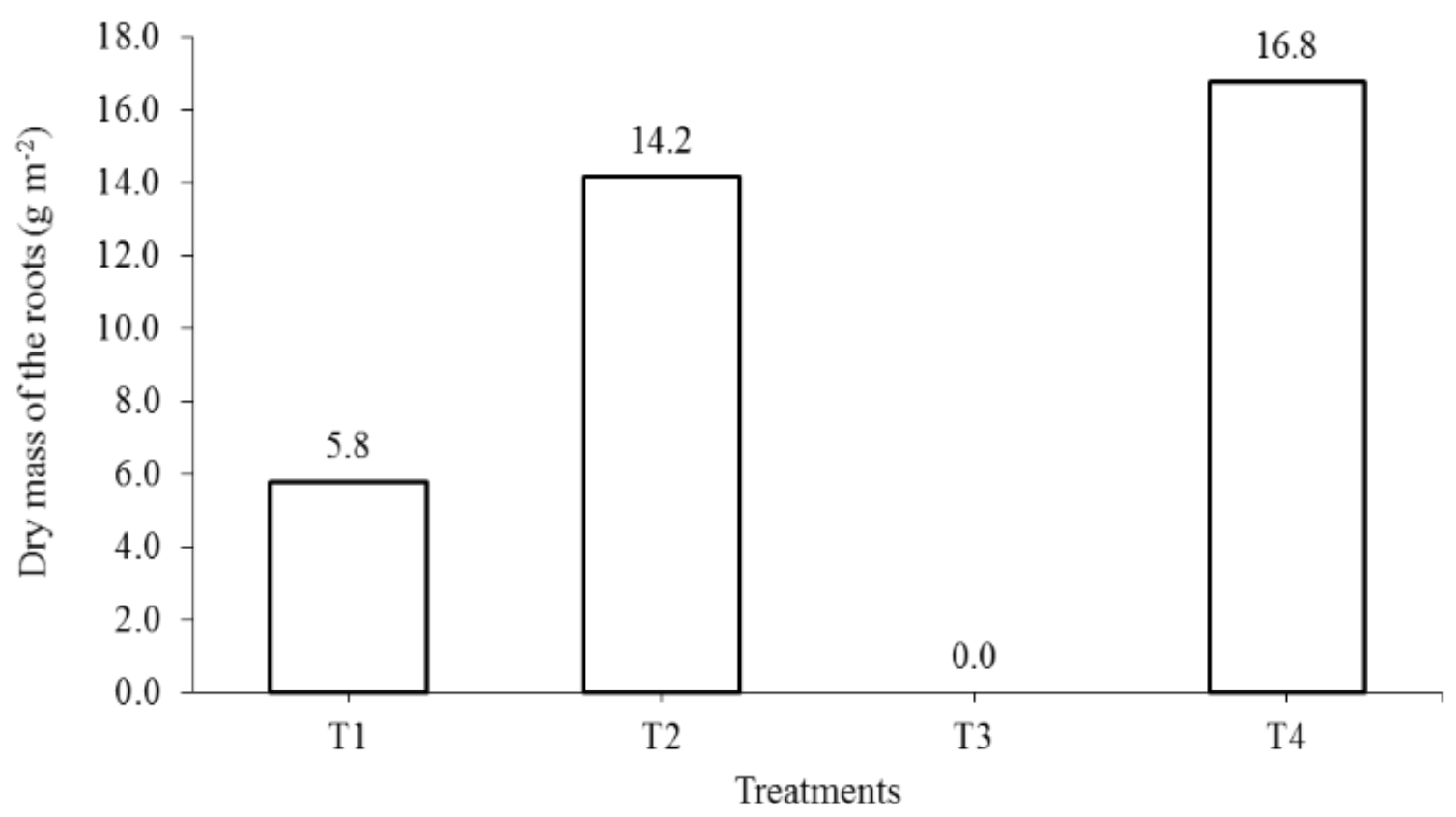

Figure 4. Dry mass of the roots of sugarcane, in $\mathrm{g} \mathrm{m}^{-2}$, for the treatments studied.

Table 2. Average dry matter mass of the roots and aerial part of sugarcane, in $\mathrm{g} \mathrm{m}^{-2}$, for the treatments.

\begin{tabular}{ccccc}
\hline \multirow{2}{*}{ Treatments** } & \multicolumn{3}{c}{ Roots $^{1}$} & Aerial part $^{2}$ \\
\cline { 2 - 5 } & 5.8 & $\mathrm{~b}$ & 21.5 & $\mathrm{C}$ \\
$\mathrm{T} 1$ & 14.2 & $\mathrm{a}$ & 73.5 & $\mathrm{~B}$ \\
$\mathrm{~T} 2$ & 0.0 & $\mathrm{c}$ & 0.0 & $\mathrm{D}$ \\
$\mathrm{T} 3$ & 16.8 & $\mathrm{a}$ & 85.4 & $\mathrm{~A}$ \\
$\mathrm{~T} 4$ & & $\mathrm{a}$ & $\mathrm{c}$ \\
\hline
\end{tabular}

*Averages followed by distinct letters, differ from each other, by the Tukey test $(\mathrm{p}<0,05) .{ }^{1} \mathrm{CV}=8,7 \% .{ }^{2} \mathrm{CV}=9,8 \% * * \mathrm{~T} 1=$ sugarcane grown under soot; $\mathrm{T} 2=$ sugarcane grown under tanned filter cake; T3 = sugarcane grown under filter cake in natura; $\mathrm{T} 4=$ sugarcane grown under enriched filter cake.

It can be stated that the use of the cured and enriched filter cake is a residue derived from sugarcane that ends up contributing significantly to the development of the roots of the crop itself and can be used in the system of production of seedlings as an improvement agent for increasing plant stability in the cultivation area. De Souza et al. (2005) evaluated the development of sugarcane under different cultural practices and concluded that the cultivation management system with the use of 
residues improves the physical conditions of the environment and increases the productive potential of sugarcane.

For the dry mass of aerial part, Figure 5 shows that the T4 treatment presented the highest value, $85.4 \mathrm{~g} \mathrm{~m}^{-2}$, differing significantly from $\mathrm{T} 2\left(73.5 \mathrm{~g} \mathrm{~m}^{-2}\right)$ and $\mathrm{T} 1\left(21.5 \mathrm{~g} \mathrm{~m}^{-2}\right)$, Table 2.

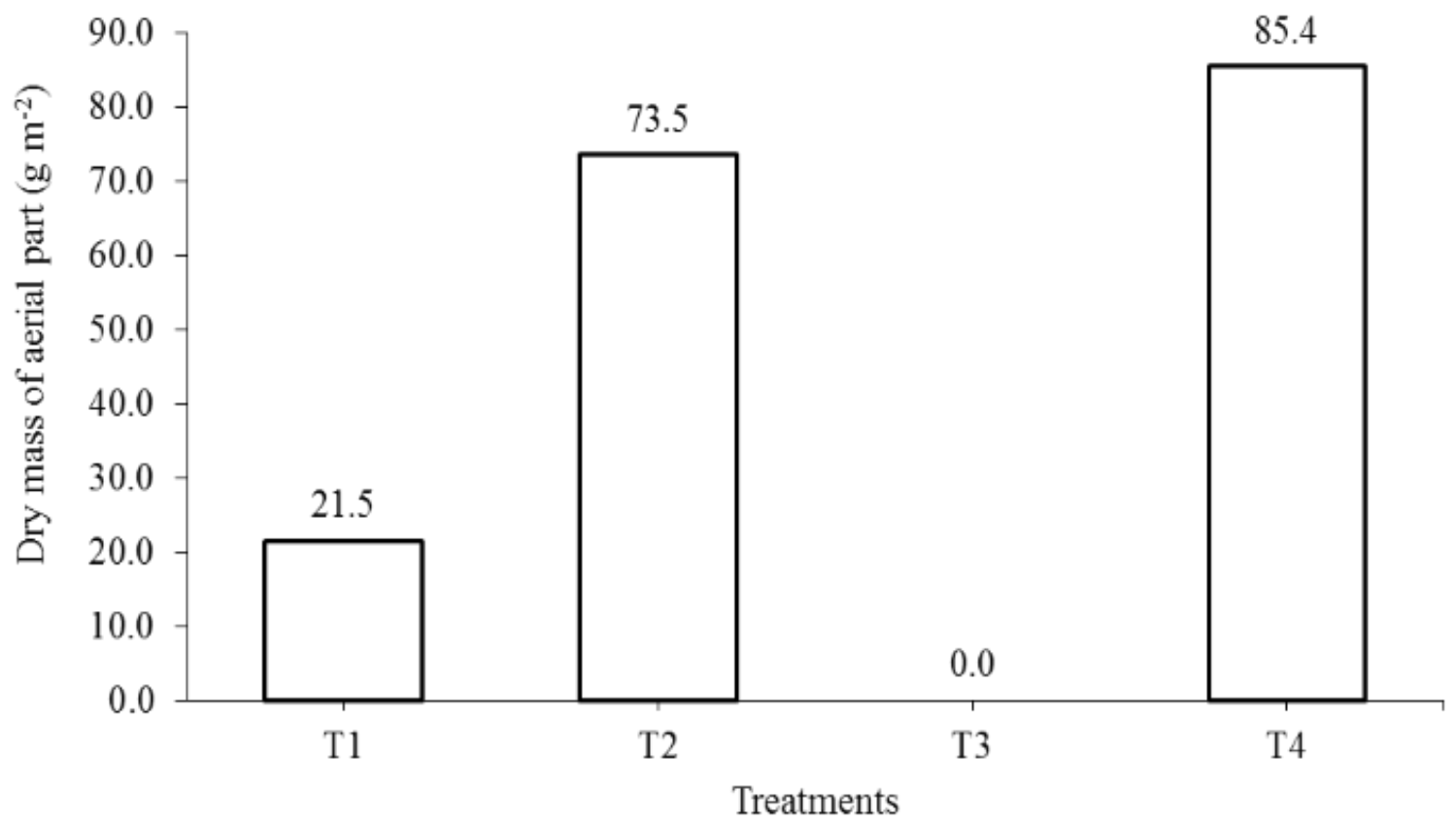

Figure 5. Dry mass of aerial part of sugarcane, in $\mathrm{g} \mathrm{m}^{-2}$, for the treatments studied.

The enriched filter cake favored directly the accumulation of essential substances present in the tillers, which during the development required a higher amount of nutrients from the cultivation environment, in order to guarantee the necessary support for the leaf formation and increase the photosynthetic rate in this period.

The effect of the nutrients added to the enriched filter cake (T4) contributed to the better development of the sugarcane seedlings for this treatment. According to Orlando Filho et al. (1999) and Dos Santos et al. (2009), the response of supplemental nitrogen fertilization and phosphate in sugarcane ends up reflecting a greater vigour of the new sprouts and increasing the production.

According to the results observed, in the treatment T1, Figure 5 and Table 2, soot did not supply the needs required by the crop during the tillering phase. Despite these results, soot is a residue that can be used in the system of production of sugarcane seedlings, and in the field, along with other organic residues, favoring the improvement of the development environment of the new sprouts. 
In treatment T2 (Figure 5 and Table 2), the use of the tanned filter cake in the sugar cane seedlings system proved to be a residue with agronomically significant results and performance, and it could also be used in other cultivations as supplemental organic fertilizer and being conducted properly in the environment. As well as for the other residues used in this work, except the filter cake in natura (T3), due to its intense fermentation process.

The analysis of the development of sugarcane conducted through the system of seedlings under different residues and compounds from the sugar and alcohol industry allows the study of the behavior and productivity of the crop grown in different scenarios, making it possible for the rural producer to plan and manage the sugarcane cultivation more efficiently in the initial stages of culture development (sprout and tillering) and to destine the residues of the sugar and alcohol industry in a more sustainable way to obtain gains in productivity and quality of the final raw material.

\section{CONCLUSIONS}

The development of sugarcane seedlings (sprout rate and tillering rate), variety RB975952, is influenced by different residues and organic compounds from the sugar and alcohol industry.

Soot, tanned filter cake and enriched filter cake, promote the development of sprouts and tillers of sugarcane.

was Also, the mortality of the sprouts for the treatment with filter cake in natura reached $100 \%$.

The treatment with enriched filter cake have a higher dry mass of aerial part in the sprouts.

\section{REFERENCES}

ALMEIDA JÚNIOR, A. B.; DO NASCIMENTO, C. W.; SOBRAL, M. F.; DA SILVA, F. B.; GOMES, W. A. 2011. Fertilidade do solo e absorção de nutrientes em cana-de-açúcar fertilizada com torta de filtro1. Revista Brasileira de Engenharia Agrícola e Ambiental, Campina Grande, , v.15, n.10, p.1004-1013.

AlveS, J. E. C.; ClEMENTE, C. V.; RODRIGUES, P. H. V. 2015. Polímero hidroretentor no desenvolvimento inicial da cultura da cana-de-açúcar. Bioenergia em Revista: Diálogos, Piracicaba,. v.5, n.1, p. 66-72.

CASAROLI, D.; QUIRIJIN, J. V. L. 2008. Critérios para determinação da capacidade de vaso. Revista Brasileira de Ciência do Solo, Viçosa, , v.32, n.1, p.59-66.

CONAB. 2016. Companhia Nacional de Abastecimento. Cana-de-açúcar: Safras e Custo de Produção. Conab, Brasília, DF, v3, n2, 72p.

CORTEZ, L.; MAGALHÃES, P.; HAPPI, J. 1992. Principais subprodutos da agroindústria canavieira e sua valorização. Revista Brasileira de Energia, Itajubá-, v.2, n.2, p.111.

CTC. 2015. Centro de Tecnologia Canavieira. Revista Censo CTC: Safra 2013/2014 - Brasil, Piracicaba, , v.1, n.1, p.16. 
DE ALMEIDA, S. M.; JERONIMO, E. M.; DAL'COL, L. A. 2008. Perfilhamento e produtividade de cana-de-açúcar com diferentes alturas de corte e épocas de colheita. Pesquisa Agropecuária Brasileira. Brasília, v.43, n.8, p.979-986.

DE SOUZA, Z. M.; DE MELLO PRADO, R.; PAIXÃO, A. C. S., CESARIN, L. G. 2005. Sistemas de colheita e manejo da palhada de cana-de-açúcar. Pesquisa Agropecuária Brasileira. Brasília, v.40, n.3, p.271-278.

DONADIO, N. M. M.; GALBIATTI, J. A.; PAULA, R. C. 2005. Qualidade da água de nascentes com diferentes usos do solo na bacia hidrográfica do Córrego Rico, São Paulo, Brasil. Engenharia Agrícola, Jaboticabal, , v.25, n.1, p.115-125.

DOS SANTOS, V. R.; FILHO, G. M.; DE ALBUQUERQUE, A. W.; DA COSTA, J. P., DOS SANTOS, C. G.; DOS SANTOS, A. C. 2009. Crescimento e produtividade agrícola de cana-de-açúcar em diferentes fontes de fósforo ${ }^{1}$. Revista Brasileira de Engenharia Agrícola e Ambiental, Campina Grande, , v.13, n.4, p.389-396.

GONZÁlEZ, L. C.; PRADO, R. D. M.; HERNÁNDEZ, A. R.; CAIONE, G.; SELVA, E. P. 2014. Uso de torta de filtro enriquecida com fosfato natural e biofertilizantes em Latossolo Vermelho distrófico. Pesquisa Agropecuária Tropical. Goiânia, , p.135-141.

JADOSKI, C. J.; TOPPA, B. E. V.; JULIANETTI, A.; HULSBOF, T.; ONO, E. O.; RODRIGUES, J. D. 2010. Physiology development in the vegetative stage of sugarcane. Pesquisa aplicada $\mathrm{e}$ Agrotecnologia, Guarapuava, v.3, n.2, p.169-186.

JADOSKI, C. J.; TOPPA, E. V. B.; RODRIGUES, J. D. 2012. Desenvolvimento mofofisiológico de raízes e brotos da cana-de-açúcar (Saccharum officinarum L.). Scientia Agraria Paranaenis, Marechal Cândido Rondon, , v.11, n.2, p.22-32.

LANDELl, M. G. A.; CAMPANA, M. P.; FIGUEIREDO, P.; XAVIER, M. A.; ANJOS, I. A.; DINARDO-MIRANDA, L. L.; SCARPARI, M. S.; GARCIA, J. C.; BIDOIA, M. A. P.; SILVA, D. N.; MENDONÇA, J. R.; KANTHACK, R. A. D.; CAMPOS, M. F.; BRANCALIAO, S. R.; Petri, R. H.; MIGUEL, P. E. M. 2012. Sistema de multiplicação de cana-de-açúcar com uso de mudas prébrotadas (MPB) oriundas de gemas individualizadas. Campinas: Instituto Agronômico de Campinas - IAC, Campinas, , 22p.

LIU, D. L.; KINGSTON, G.; BULL, T. A. 1998. A new technique for determining the thermal parameters of phenological development in sugarcane, including suboptimum and supra-optimum temperature regimes. Agricultural and Forest Meteorology, Australia, v.90, n.1, p.119-139.

MARAFON, A. C. 2012. Análise quantitativa de crescimento em cana-de-açúcar: uma introdução ao procedimento prático. Aracaju, SE: Embrapa Tabuleiros Costeiros, 29p.

OLIVEIRA, A. R.; BRAGA, M. B.; SANTOS, B. L. S. 2014. Produção de biomassa de cana-de-açúcar no vale do São Francisco. Energia na agricultura, Botucatu, , v.29, n.1, p.27-38.

ORLANDO FILHO, J.; RODELlA, A. A.; BELTRAME, J. A.; LAVORENTI, N. A. 1999. Doses, fontes e formas de aplicação de nitrogênio em cana-de-açúcar. Sociedade dos Técnicos Açucareiros e Alcooleiros do Brasil - STAB, Piracicaba, , v.17, p.39-41.

PAUlA, M. O.; TINÔCO, I. F. F.; RODRÍGUES, C. S.; SILVA, E. N.; SOUZA, C. F. 2009. Potential of sugarcane bagasse ash as a partial replacement material for Portland cement. Revista Brasileira de Engenharia Agrícola e Ambiental. Campina Grande, , v.13, n.3, p.353-357.

PEEL, M. C.; FINLAYSON, B. L.; MCMAHON, T. A. 2007. Updated world map of the Köppen-Geiger climate classification. Hydrology and earth system sciences discussions, European Geosciences Union, v.4, n.2, p.439-473.

RIDESA. 2015. Rede Interuniversitária para o Desenvolvimento do Setor Sucroenergético. 45 Anos de variedades RB de cana-de-açúcar: 25 anos de Ridesa. Curitiba, , 156p. Available at: 
https://www.academie-agriculture.fr/system/files_force/sections/section-1/fichiersprives/livro45anos.pdf?download=1. Access: November, 2016.

SERAFIM, L. G. F.; STOLF, R.; SILVA, J. R.; SILVA, L. C. F.; MANIERO, M. A.; BASSINELLO, A. I. 2013. Influência do plantio mecanizado no índice de brotação da cana-de-açúcar. Sociedade dos Técnicos Açucareiros e Alcooleiros do Brasil - STAB, Piracicaba, SP, v. 31, n. 3, p. 21-25.

SCHNEIDER, C. F.; SCHULZ, D. G.; LIMA, P. R.; JÚNIOR, A. C. G. 2013. Formas de gestão e aplicação de resíduos da cana-de-açúcar visando redução de impactos ambientais. Revista Verde de Agroecologia e Desenvolvimento Sustentável, Pombal, , v. 7, n. 5, p. 08-17.

VASCONCELOS, A. C. M.; GARCIA, J. C. 2005. Desenvolvimento radicular da cana-de-açúcar. Potafos - Encarte de Informações Agronômicas, Georgia, , n.110, 5p.

VITTI, G. C.; OLIVEIRA, D. B.; QUINTINO, T. A. 2006. Micronutrientes na cultura da cana-de-açúcar. In: SEGATO, S. V. et al. (Org.). Atualização em produção de cana-de-açúcar. Piracicaba: CP 2, p. 121-138.

TAVARES, O. C. H.; LIMA, E.; ZONTA, E. 2010. Crescimento e produtividade da cana planta cultivada em diferentes sistemas de preparo do solo e de colheita. Acta Scientiarum Agronomy, Maringá-, v.32, n.1, p.61-68. 